\section{A NEW SPECIES OF OXYTROPIS FOR ALBERTA}

by Keith Shaw, Cardston, Alberta

On May 16, 1958 specimens of an unknown Oxytropis were collected from gravelly soil on a south slope near the town reservoir at Cardstion in southwestern Alberta. Since species determination was impossible from manuals available at that time, duplicates were sent to graduate student (now Ph.D.) Stanley L. Welsh, who was working on the Leguminosae at Iowa State College. Mr. Welsh identified these specimens as Oxytropis lagopus Nutt. var. conjugans Barneby. Verification was made by Rupert C. Barneby, noted authority on Oxytropis, of The New York Botanical Garden.

There are two varieties of the species $O$. lagopus Nutt. The var. atropurpurea (Rydb.) Barneby, is known only from Wyoming, extreme southern Montana and the peaks of the Black Hills. The var. conjugans Barneby has previously been reported from western Montana only. (Barneby, R. C. 1963. Notes on Oxytropis. Leaflets of Western Botany, Vol. X, No. 2).

Description of Oxytropis lagopus Nutt. var. conjugans Barneby: The pods are erect or spreading; stipules adnate to the petioles; plants scapose or subscapose. Inflorescence is not glandular viscid. Leaves are strictly pinnate. Racemes are 6- to manyflowered, rarely elongating in fruit. Corolla is a deep purplish-blue with a yellowish-orange base. Pods are not inflated; $5 \mathrm{~mm}$. wide or less, gradually narrowed to a beak in fruit. Calyx with spreading hairs; inflorescence subcapitate; pubescence of foliage composed entirely of basifixed hairs.

Duplicates (R. K. Shaw 35) of Oxytropis lagopus Nutt. var. conjugans Barneby are in the herbaria of Brigham Young University, Provo, Utah and Iowa State College, Ames, Iowa.

\section{A MOST VERSATILE SHRUB}

by Gordon Smith, Winnipeg

With approaching spring many Blue Jay readers will be considering ways of attracting birds about the premises. Those who are thinking of planting a few berry-producing shrubs might try the Red Osier Dogwood, not only for the abundant fruit produced, but also for the masses of flower clusters with their delicate perfume. In the autumn the multi-hued leaves make it one of the most colorful of prairie shrubs, and, when the leaves have fallen, the red-barked branches are most attractive amidst the winter snow. Unfortunately the berries do not remain throughout the winter, but you can't have everything.

The Red Osier Dogwood (Cornus stolonifera) is perhaps the most wide ranging of the family in Canada, if not North America, and is found in varied habitats ranging from wet swampy areas, prairie woodland and dry sand hills. As the fruiting period extends from early July to late September in the prairie region its importance to birds as a food source cannot be underestimated. Robin's, especially, feed on dogwood berries extensively during the hot dry summer when earth-worms are unobtainable and many young appear to be fed nothing else by their parents.

Two dogwoods in my backyard are now probably at their maximum height (6-7 feet) and have produced steadily for about seven years. While they have no doubt received more attention than they would in the wild they really don't require any fuss if you just want a "bushy" area for shelter and food. For the best shrubs I recommend digging your own, preferably from loose soil for less root disturbance. When they are once established the birds will provide a steady supply of seedlings, via droppings.

Besides Robins, other birds which I have observed eating the dogwood fruit include the Yellow-shafted Flicker, Eastern Kingbird, Empi- 
donax Flycatcher (believed Least), Red-eyed Vireo, Cedar Waxwing, Catbird, Brown Thrasher, Baltimore Oriole, Swainson's Thrush, Whitethroated and Harris' sparrows (readers can no doubt add others). All these species swallowed the berries whole excepting the finches; they discarded the pulp for the seeds inside the large stone.

\section{OWL'S-CLOVER}

\section{by Keith F. Best, Swift Current}

Owl's-clover (Orthocarpus luteus Nutt.), sometimes called orthocarp, is a relatively small annual herb of the figwort family, ranging from British Columbia to Saskatchewan through Nebraska to New Mexico and California. It grows in a wide variety of soils, both dry and moist, from the sagebrush belt to the spruce-fir belt. Although probably most common on grasslands or in grass-weed types, it also occurs in bush and timbered areas. It grows more abundantly in meadows and parklands where the original vegetation has been reduced; consequently owl's-clover frequently is abundant on areas where the cover of more palatable plants has been somewhat depleted by overgrazing.

Owl's - clover derives its generic name Orthocarpus from the Greek words orthos, upright, and karpos, fruit, and it refers to the erect seed pods. The specific name luteus, is Latin for yellow and refers to the color of the flowers. This species is often called yellow owl's-clover or gold-tongue.

Blooming in late July and throughout August, owl's-clover is quite common on the dry, open prairie. Usually a single-stemmed erect annual, it is often found branched, a condition due to terminal bud damage by grazing. The leaves are one-half to one and one-half inches long, linear or narrowly lanceolate, lying relatively close to the stem and ascending. The yellow or gold flowers are borne in dense, leafy terminal spikes, interspersed with green bracts that are often tinged with red. The corolla of the flower is strongly two-lipped, the upper lip being erect or arched, while the lower one is more or less spreading and usually three-lobed. The stamens are arranged in two pairs, ascending under the upper lip.

The species deserves notice because of its commonness and wide distribution, and because it is a representative member of a rather large genus of range species of somewhat unusual appearance. The plants are usually small, produce very little herbage, and are generally low in palatability. Accordingly, owl's-clover is of minor consequence as a forage species. It is practically worthless for cattle and only poor to fair sheep forage.

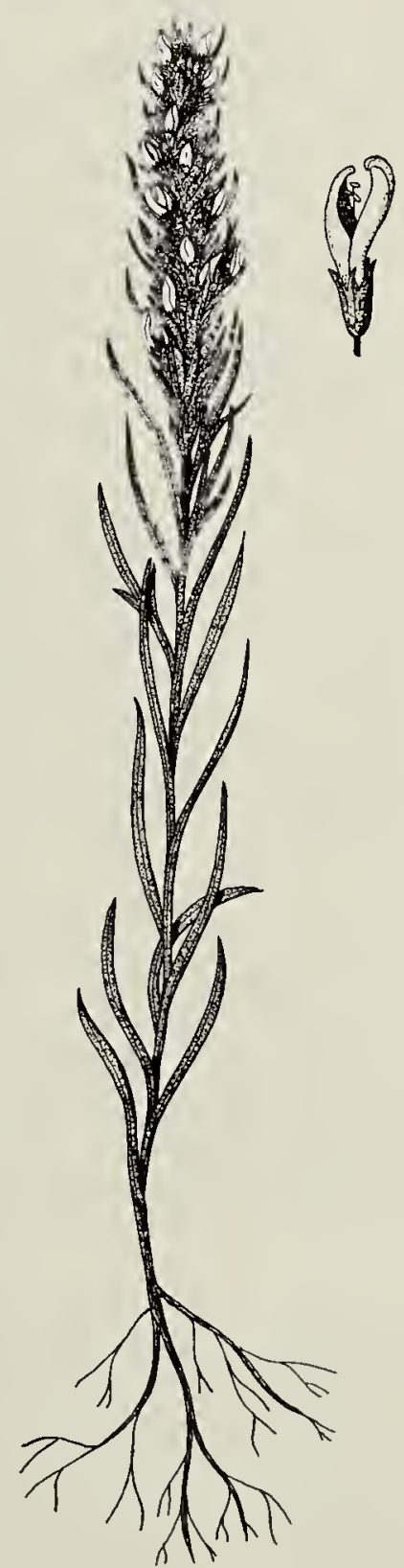

Drawing by $K$. F. Best

Owl's-clover Orthocarpus luteus 